\title{
Trafficability Prediction Using Depth-to-Water Maps: the Status of Application in Northern and Central European Forestry
}

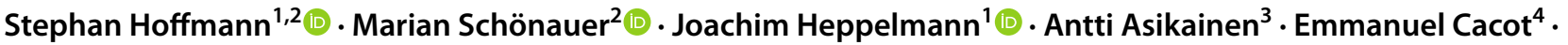

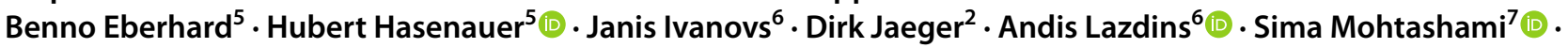

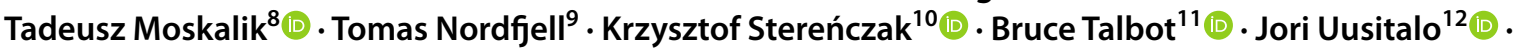 \\ Morgan Vuillermoz ${ }^{13} \cdot$ Rasmus Astrup $^{1}$
}

Accepted: 9 December 2021 / Published online: 8 January 2022

(c) The Author(s) 2022, corrected publication 2022

\begin{abstract}
Purpose of Review Mechanized logging operations with ground-based equipment commonly represent European production forestry but are well-known to potentially cause soil impacts through various forms of soil disturbances, especially on wet soils with low bearing capacity. In times of changing climate, with shorter periods of frozen soils, heavy rain fall events in spring and autumn and frequent needs for salvage logging, forestry stakeholders face increasingly unfavourable conditions to conduct low-impact operations. Thus, more than ever, planning tools such as trafficability maps are required to ensure efficient forest operations at reduced environmental impact. This paper aims to describe the status quo of existence and implementation of such tools applied in forest operations across Europe. In addition, focus is given to the availability and accessibility of data relevant for such predictions.

Recent Findings A commonly identified method to support the planning and execution of machine-based operations is given by the prediction of areas with low bearing capacity due to wet soil conditions. Both the topographic wetness index (TWI) and the depth-to-water algorithm (DTW) are used to identify wet areas and to produce trafficability maps, based on spatial information.

Summary The required input data is commonly available among governmental institutions and in some countries already further processed to have topography-derived trafficability maps and respective enabling technologies at hand. Particularly the Nordic countries are ahead within this process and currently pave the way to further transfer static trafficability maps into dynamic ones, including additional site-specific information received from detailed forest inventories. Yet, it is hoped that a broader adoption of these information by forest managers throughout Europe will take place to enhance sustainable forest operations.
\end{abstract}

Keywords Depth-to-water · Remote sensing · Digital terrain models · European forestry · Precision forestry · Trafficability prediction

\section{Introduction}

In Central and Northern European countries, groundbased harvesting equipment accounts for the vast majority of commercially supplied roundwood. These predominantly cut-to-length operations are usually performed by

This article is part of the Topical Collection on Forest Engineering

Stephan Hoffmann

stephan.hoffmann@nibio.no

Extended author information available on the last page of the article harvester-forwarder systems unavoidably impacting the soil ecosystems due to high machine and payload weight transported over sensitive forest grounds [1]. Such impacts occur in various forms and include soil deformations such as ruts $[2,3]$, or soil compaction, which increases bulk density due to a decreasing pore space $[4,5]$, restricting the permeability of the soil [6]. The occurring degree of damage is a function of the traffic experienced, site conditions such as soil type, climate variables and machine operator skills $[1,7]$.

Historically, the primary timber logging season was scheduled for the winter periods when the soils are frozen $[8,9]$, making them relatively resilient to impacts due to 
their increased bearing strength [10]. Yet, the high ownership costs of modern logging equipment and involving supply chains require these machines to work year-round with the capability to increase their loads for cost reduction in an increasingly complex business environment with global competition [11]. Moreover, time periods of favourable operational conditions, in terms of frozen and thus stable soils, are getting shorter and less frequent [5, 12]. On the other hand, periods of freeze and thaw cycles with wet or even water-saturated soil conditions are likely to be extended, resulting in vulnerable soils with restricted trafficability [13]. This leads to a more significant potential for lasting site damages caused by heavy machinery in the form of soil rutting or compaction [14] and is thus a major concern during sustainable impact assessment of forest operations and timber supply chains [15].

The occurrence of severe soil impacts can be associated with several negative effects, including both economic and ecological aspects. For instance, more machine power is required when machines are driving on soft grounds, resulting in increased fuel consumption, machine wear and technical failures $[16 \bullet, 17]$. Moreover, ongoing operations need to be stopped if the occurring rut depth exceeds degrees or extents defined in contracts made between entrepreneurs and forest owners, resulting in high costs due to machine relocations and downtime.

In addition to economic drawbacks, various trafficinduced environmental consequences are of concern. The compaction of soil in a continuous linear pattern, such as a wheel track, restricts the soil's permeability and alters hydrological conditions [18]. On steeper slopes, ruts can result in channelling with increasing erosional energy, fortifying the loss of valuable topsoil [19]. When exceeding a specific soil bulk density, negative effects on plant available water [20] and plant growth [21, 22] can occur. Beylich et al. [23] report negative effects on various soil faunal groups related to the reduced macropore volume and the altered hydrological conditions. In addition, soil disturbance through rutting has also been suspected of mobilizing heavy metals, e.g. methyl-mercury, although the direct effect of soil disturbance alone has not been quantified [24-26].

In consequence, it is critically noted that forestry machines have increased in total weight over the last decades [27]. However, the pressure exerted by heavy forwarders on the ground did not increase, as a result of likewise increased contact area between machine and soil [28]. Along with wider and optionally low inflatable tyres [29], numerous technological solutions aim to mitigate traffic-induced site impact. Hereby, a focus is set on increasing machine flotation, traction and contact area, as for example through bogie tracks [30], long-tracked bogie axles [31], triple-bogie axles [32], auxiliary axles [33], rubber-tracked bogie axles with support rollers [34], large radial tyres with alternative treads [35], the utilization of traction-assist winches [36], brush mats [37] and innovative steering concepts [38].

However, an efficient utilization of technical soil prevention measures relies upon the information of soil state in advance of scheduled operations. This enables the selection of adequate equipment and sites to be operated in actual instructions for machine drivers, as well as a sufficient support during the off-road navigation in forest stands. The potential avoidance of areas and sites possessing a currently high vulnerability to machine impact implies the spatial prediction of risks to severe damages — both, among extensive off-road traffic during clear-cut operations, as common in Nordic countries, but also among single-selection silviculture systems commonly practiced in Central Europe, where machine traffic is often confined to permanent machine operation trails. There, next to the reduction of soil impacts in general, the technical functionality and consequent permanent accessibility into forest stands can be maintained if machine operators know which segments of a machine operating trail to avoid at a given time of operation. Field testing equipment such as penetrologger, penetrometer or vane testers are easy to handle tools, generating established indices about soil strength [39]. However, assessing an entire operation site with these tools is time consuming and represents only the current situation at time of measurement. Thus, there is an increasing role for planning software solutions with predictive power for different conditions expected and demanded in harvesting preparations [40-42].

A number of rut risk prediction tools have been developed in the last decades: A simplified model was suggested by O'Sullivan et al. [43], in which contact areas between soil and tires, soil type, initial bulk density and water content profiles are considered for the selection of an appropriately equipped machine. A similar approach was invented by Canillas and Salokhe [44], who added external variables like travel speed, axle loads and number of passes to tire and soil variables, to develop a decision support system, providing recommendations for soil management practices on agricultural areas. Still, a regular application of such systems in day-to-day forestry operations is pending. It can be assumed that a reason for a lacking implementation of predictive systems into forest management can be found in the high demand of required input data, or time-intensive efforts for related in-field measurements [39]. Consequently, topical research emphasizes the utilization of openly accessible data, as for example shown by the work of Lidberg et al. [45•], who generated wet area maps based on data from national inventories, fused with topographical information, including the topographic wetness index (TWI) and depthto-water (DTW) maps. Salmivaara et al. [46••] developed an integrative tool to predict trafficability, using a spatial hydrological model, inventory data, a wide range of spatial information and data derived from the operating machine. 
The increasingly available ALS (airborne laser scanning)derived digital terrain models (DTM) have been verified by the plethora of their various applications, both for practical and scientific purposes. Perhaps one of the most significant applications of ALS-derived DTMs in forest operations has been in facilitating the mapping of areas of anticipated high moisture and therewith potentially high vulnerability to soil damage by vehicle passes. The nowadays wide availability of high-resolution DTMs (i.e. 0.5-2 m grid cell size) allows for precise application of spatial parameters useful to determine soil trafficability sensitivity, such as the TWI developed by Beven and Kirkby [47]. This index quantifies the influence of topography on hydrological processes based on slope and upstream contributing area. Researchers have evaluated TWI's successfulness in predicting the groundwater table [48], the effect of DTM resolution on its prediction [49] and how it performs in comparison to a dynamic model [50]. There are several possible methods to calculate the contributing area, flow channels and slope out of a DTM for the TWI index, partly with local alterations.

The cartographic DTW algorithm, developed by Murphy et al. [51, 52], has proven to be powerful in the prediction of soil state across different landscapes [52, 53]. This algorithm was evaluated to be more independent from the scale of the DTM provided, as compared to other topography-derived algorithms, such as the TWI [54]. This allows for reliable results even when the calculations are based on input grid cells of different resolutions, thus having an asset over the TWI.

Due to the rising interest in the DTW-based trafficability assessment by researchers and industry, our paper aims to give an overview and synthesizing the readiness level for the implementation of national terrain simulations, applying the DTW algorithm. Relevant forestry countries in Northern and Central Europe have been selected to review the status of available terrain data derived from state-of-the-art airborne laser scanning (ALS) technologies-a fundamental prerequisite to produce DTW maps. Further, already existing applications of the DTW algorithm or other means of spatial trafficability prediction to reduce the impact of ground-based logging systems are presented among the selected countries, too. Hence, this paper provides an assessment of the status and the potential integration of such tools to support sustainable forest management by improved operational planning and execution.

\section{Literature Review}

Review articles are commonly based on the screening of scientific publications, identified through a search string of selected keywords in combination with Boolean operators applied to a publication database such as the Web of
Science. Although this review approach facilitates a logical identification of publications assigned to a specific topic, it also often leads to hundreds of selections which are not relevant for the review's objective and need to be manually eliminated through a time-consuming initial examination of at least the title or the abstract.

This review on the DTW algorithm in the context of trafficability mapping follows the snowball approach, where the bibliography of a known recent key publication, in this case Salmivaara et al. [46••], is used as a starting point to identify further publications. Subsequently, selected publications were reviewed and those bibliographies used to identify additional publications until no more new references of relevance appeared. A priority was given to publications of the last decade (2011-2021), following the wider promotion of forest soil moisture modelling for operational purposes in 2011 by Murphy et al. [52]. This approach was selected since in contrast to a purely keyword focused database search, the snowball system considers all relevant references, including non-peer-reviewed early-stage research, as well as institutional and industry reports. Moreover, the authoring team consists of experts on the topic, being involved in the two multiyear EU projects TECH4EFFECT (grant number 720757) and EFFORTE (grant number 720712), which conducted intensive research in the field of trafficability prediction. Thus, additionally to the relevant state-of-the-art publications, latest findings from ongoing research and technical implementation on national level could be incorporated into the review process. Through this rather open approach, 56 peer-reviewed publications, 14 web resources and 8 institutional reports of relevance directly involving or related to forest site trafficability prediction with the DTW algorithm could be identified and reviewed for the period of interest.

\section{Conception of the Depth-to-Water Algorithm and Its Application for Trafficability Mapping}

DTW uses flow lines derived from a DTM-based flow accumulation, to calculate the anticipated vertical distance between any given grid cell of a DTM to a modelled water layer [55]. Each grid cell's accumulated flow value is computed based on the size of the area, converging from the adjacent cells. The accumulated area size is then used to initiate a flow line, depending on a defined threshold. This threshold of area size defines the flow initiation area (FIA, $\mathrm{m}^{2}$ ). For example, if the FIA was set to $2,500 \mathrm{~m}^{2}$, an accumulated value of $2,500 \mathrm{~m}^{2}$ was sufficient to start a flow line, which continues until leaving the area of interest. If a large FIA is used to initiate a simulated flow line, a low level of soil moisture is represented in return. Contrarily, a small FIA can be used to represent very wet or sensitive soil conditions, as the network of flow lines expands. 
The flow lines created in this way are added as a dichotomous value to the respective DTM. The combination of both flow lines and DTM can be used to compute the vertical difference between each grid cell and the nearest flow linedefining the DTW index. Therefore, a least cost function is applied to estimate the least slope gradients between the grid cells and the flow lines, minimizing Eq. (1):

$D T W[\mathrm{~m}]=\left[\sum \frac{d z_{i}}{d x_{i}} a\right] x_{c}$

where $\frac{d z_{i}}{d x_{i}}$ is the slope between a cell $i$ and adjacent cells, $a$ is 1 in case of parallel drainage and $\sqrt{2}$ in case of diagonal drainage and $x_{c}$ is the grid cell size $(\mathrm{m})$.

For enhanced utilization of the DTW concept, the procedure was described in detail and made openly available by Schönauer and Maack [56]. The DTW index can be interpreted as a relative measure of soil drainage condition, which approximates the tendency of a saturated landscape point. Cells with a small DTW value show a trend of surface water or water containing layers in the soil [51]. In return, high values of DTW are assumed to indicate dryer soils (Fig. 1).

Since the susceptibility of soils to deformations is deeply attributed to the soil moisture content [57], DTW maps are increasingly used to assess the risk of causing machine traffic-induced rutting and compaction [39, 58]. DTW maps can be adopted by the forest industry to plan operations and guide machine traffic. Such a planning approach can be used for instance to identify and avoid potential wet areas, streams which are not visible due to a snow cover, or to optimize the delineation of a machine operating trail across forest stands. An integrated on-board navigation system in harvester and forwarders could then be used to identify and warn operators when approaching sensitive areas within a harvesting unit. Zimbelman and Keefe [59] demonstrated the use of geofencing tools to notify workers of high hazard zones in forestry activities. Similar activities could be developed that integrate the mapping of soft soils and actively inform the operator when they approach those areas. However, it would also require additional training to ensure that the operators can quickly implement this information to improve forest management's sustainability.

Recent studies reveal a possible fusion of DTW maps with further data sources, including openly accessible spatial information and hydrological modelling, to be used for the prediction of forest soil's trafficability [45•, 46••] and improve the off-road navigation of forest machines [60•, 61]. Such approaches profit vastly from open and cross-border availability of spatial data [62]. In particular, the European Community INSPIRE Directive implemented public availability of manifold data sets [63]. Through the INSPIRE programme, 34 spatial data themes needed for environmental applications, such as elevation, are compiled and organized in a standardized infrastructure for sharing among public organizations, but also providing public access on a European scale, aiming towards an enhanced land-use policymaking across boundaries [64].

\section{Country Overview and Readiness for DTW}

Countries are collecting spatial data from regional to national level, characterized by differences in survey technology, processing and provision to users (Table 1). In consequence, this determines the DTW readiness for operational purposes within a specific country. Therefore, a detailed overview of national ALS mapping campaigns and derived DTM accessibility shall be given for selected key forestry
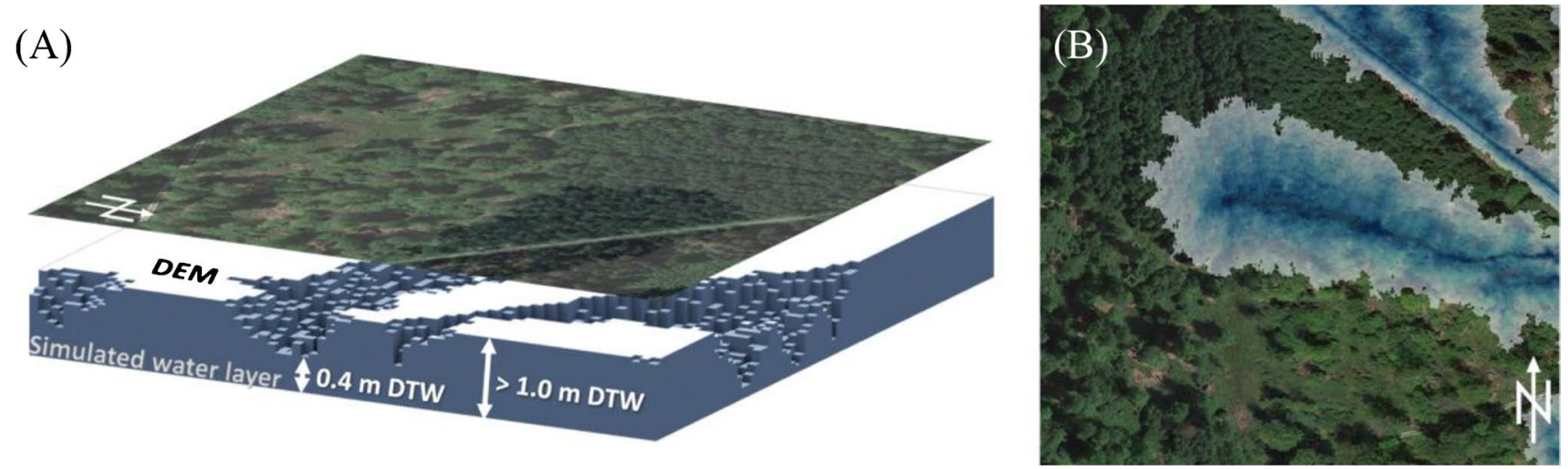

Fig. 1 The depth-to-water index (DTW) indicates the vertical proximity to the nearest simulated water layer, which is based on flow lines or areas saturated by water. Particularly, this metric index is calculated for each cell of a digital terrain model (DTM). A Values less than $1 \mathrm{~m}$ indicate wet areas with high susceptibility for soil deforma- tions, whereas values greater than $1 \mathrm{~m}$ should possess sufficient trafficability for heavy forest machines. B Thus, areas with a high risk for soil damage can be shown on maps, as indicated by the blue colouring 
Table 1 Overview of the availability and quality of digital terrain models in selected European countries

\begin{tabular}{|c|c|c|c|c|c|c|}
\hline Country & Grid cell size & Data acquisition & $\begin{array}{l}\text { Year of national } \\
\text { campaign }\end{array}$ & ALS resolution & Source & Costs \\
\hline \multirow[t]{2}{*}{ Austria } & $10 \mathrm{~m}$ & $\begin{array}{l}\text { National ALS cam- } \\
\text { paign }\end{array}$ & 2013 & $4 \mathrm{pts} / \mathrm{m}^{2}$ & www.data.gv.at & Open access \\
\hline & $1 \mathrm{~m}(0.5 \mathrm{~m})$ & $\begin{array}{l}\text { State-individual ALS } \\
\text { campaigns }\end{array}$ & \multicolumn{2}{|l|}{ Varying between states } & & \\
\hline Finland & $2 \mathrm{~m}$ & $\begin{array}{l}\text { National ALS cam- } \\
\text { paign }\end{array}$ & \multirow[t]{3}{*}{ Accomplished 2020} & 0.5 to $1 \mathrm{pts} / \mathrm{m}^{2}$ & www.paituli.csc.fi & Open access \\
\hline \multirow[t]{2}{*}{ France } & \multicolumn{2}{|c|}{ National ALS campaign in progress } & & & & \\
\hline & 25,75 and $250 \mathrm{~m}$ & $\begin{array}{l}\text { Various sources } \\
\text { according to } \\
\text { regional acquisition } \\
\text { approaches }\end{array}$ & & Not applicable & & $\begin{array}{l}\text { Open access down } \\
\text { to } 75 \mathrm{~m}, 25 \mathrm{~m} \text { with } \\
\text { costs }\end{array}$ \\
\hline \multirow[t]{3}{*}{ Germany } & $200 \mathrm{~m}$ & \multirow{3}{*}{$\begin{array}{l}\text { Various sources } \\
\text { according to } \\
\text { regional acquisition } \\
\text { approaches }\end{array}$} & \multirow{2}{*}{$\begin{array}{l}\text { Update based on } \\
\text { regional data } \\
\text { provision }\end{array}$} & \multirow[t]{2}{*}{ Diverse } & \multirow{3}{*}{$\begin{array}{l}\text { www.bkg.bund.de } \\
\text { and www.geopo } \\
\text { rtal.de }\end{array}$} & Open access \\
\hline & $5 \mathrm{~m}$ & & & & & $\begin{array}{l}\text { Individualized } \\
\text { licensing scheme }\end{array}$ \\
\hline & $1 \mathrm{~m}$ & & \multicolumn{2}{|l|}{ Varying between states } & & \\
\hline Latvia & $20 \mathrm{~m}$ & $\begin{array}{l}\text { National ALS cam- } \\
\text { paign }\end{array}$ & 2013-2019 & $4 \mathrm{pts} / \mathrm{m}^{2}$ & www.lgia.gov.lv & Open access \\
\hline Norway & $\begin{array}{l}10 \mathrm{~m} \text { (national } \\
\text { level, locally } \\
\text { higher) }\end{array}$ & $\begin{array}{l}\text { National ALS cam- } \\
\text { paign and regional } \\
\text { orthophotos }\end{array}$ & $\begin{array}{l}\text { Updating campaign } \\
\text { 2016-2022 }\end{array}$ & $\begin{array}{l}\text { Min. } 2 \text { pts } / \mathrm{m}^{2} \\
\quad \text { (locally higher) }\end{array}$ & www.hoydedata.no & Open access \\
\hline Poland & $0.5 \mathrm{~m}(1 \mathrm{~m})$ & $\begin{array}{l}\text { National ALS cam- } \\
\text { paign }\end{array}$ & Since $2011-2014$ & 4,6 and $12 \mathrm{pts} / \mathrm{m}^{2}$ & www.gugik.gov.pl & Open access \\
\hline \multirow[t]{2}{*}{ Sweden } & $2 \mathrm{~m}$ & $\begin{array}{l}\text { National ALS cam- } \\
\text { paign }\end{array}$ & $\begin{array}{l}\text { 2009-2016 (new } \\
\text { campaign since } \\
\text { 2018) }\end{array}$ & $0.5-1 \mathrm{pts} / \mathrm{m}^{2}$ & $\begin{array}{l}\text { www.lantmateriet. } \\
\text { se and www.geoda } \\
\text { ta.se }\end{array}$ & $\begin{array}{l}\text { Free access for } \\
\text { research and } \\
\text { education, yearly } \\
\text { subscription fee } \\
\text { for commercial } \\
\text { applications }\end{array}$ \\
\hline & $50 \mathrm{~m}$ & $\begin{array}{l}\text { Various sources } \\
\text { according to } \\
\text { regional acquisition } \\
\text { approaches }\end{array}$ & & Not applicable & & Open access \\
\hline
\end{tabular}

countries. Namely, the Nordic countries Finland and Sweden were selected due to its high degree of mechanized operations with heavy logging equipment, as well as a considerable share of sensitive operation sites such as peatlands. Norway, with its more mountainous landscapes, completes the boreal forest biome of the Nordic countries. In Central Europe, Germany and France are representing diverse temperate forest regions of major timber-producing countries, applying a wide range of silvicultural and operational systems. Austria, following similar forestry approaches, is included to represent the high mountain regions of Central Europe. East-Central Europe is represented by Poland as an important timber producer with vast forest areas shaped by continental climate conditions. Furthermore, Latvia was added to represent the specific Baltic conditions with seasonally waterlogged plains.

Next to the acquisition and provision of terrain data, the current availability or implementation of DTW maps and
non-DTW-based trafficability prediction in the selected countries is surveyed within this review.

\section{State of Operational Moisture-Driven Trafficability Modelling}

\section{Finland}

Forest owners in Finland can estimate forest soil trafficability with two alternative methods: with the DTW maps or with the static trafficability maps developed by Arbonaut Oy.

The DTW maps are based on $2 \mathrm{~m}$ DTMs practically available for the whole country. Various stream networks are calculated by using 0.5 ha, 1 ha, 4 ha and 10 ha threshold on the flow accumulation raster. The DTW is finally calculated based on these stream networks and slope with cost accumulation per watershed, which is conducted by Luke, and 
the maps are available in the national spatial data download service (www.paituli.csc.fi).

The static trafficability map presents the classification of forests in 6 different trafficability classes. The map product, developed by Arbonaut Oy, combines classic topographic DTW information to tree volume and soil type (peatland or mineral soil). The trafficability classes are based on seasonal changes in bearing capacity of forest floor in Finland. The map provides information about the season when harvesting operations may take place with standard logging machinery (i.e. a harvester and a forwarder) without causing substantial damages on forest soil. The mapping unit is a pixel of $16 \mathrm{~m}$ size compatible with the forest resource information provided by the Finnish Forest Centre. Each pixel is classified in one of the following classes: 1, operations possible in all seasons; 2 , operations possible in summer, mineral soils; 3 , operations possible in summer during dry season, mineral soils; 4 , operations possible in summer, peatlands; 5 , operations possible in summer during dry season, peatlands; and 6, operations possible only during frost or thick layer of snow [65].

The trafficability maps are available for the whole country. The data is distributed as open access data by the Finnish Forest Centre. The data can be accessed via a map application and a web map service WMS. Also, the raster maps can be downloaded from the Finnish Forest Centre's www site (https://aineistot.metsaan.fi/avoinmetsatieto/Korjuukelp oisuus) as tif files. In addition, forest owners can access the data in www.metsaan.fi service portal. Metsaan.fi is a service for forest owner to easily access the information of their own forest and to use digital forest services. The trafficability maps are today widely used in Finnish forestry by forest operation managers and forest machine operators [66].

\section{Sweden}

The Swedish Mapping, Cadastral and Land Registration Authority, Lantmäteriet, scanned the entire country with high-resolution ALS technology between 2009 and 2016 to provide detailed terrain model required for climate change adaptation programmes and other environmental programmes [67]. The scanning was performed from airplanes at an altitude of $1,700-2,300$ and up to $3,500 \mathrm{~m}$ in the mountains, on areas of $25 \times 50 \mathrm{~km}$, and collect data in the form of point clouds. The point intensity in scanning varies between 0.5 and 1 per $\mathrm{m}^{2}$. It has an average error of $25 \mathrm{~cm}$ planar direction in the reference system SWEREF $99 \mathrm{TM}$ and $5 \mathrm{~cm}$ in elevation in the reference system RH 2000. Using triangular irregular network (TIN) interpolation, the point data is transformed to a 2-m elevation grid with a precision that is better than $10 \mathrm{~cm}$ in height and $30 \mathrm{~cm}$ in planar [67]. The data set is freely available for research and education but requires subscription fee for commercial application. Elevation data, grid 50, is another terrain model available at the Swedish Mapping, Cadastral and Land Registration Authority. This model is built based on either the (1) national terrain model or (2) the elevation data bank (from the 1980s) and are used in more general applications, e.g. height contours generations and correction of satellite images.

A new nationwide LiDAR campaign with higher point density $\left(1-2 \mathrm{pts} / \mathrm{m}^{2}\right)$ has just started in spring 2018, mainly to update the forest estimations, e.g. tree volume, height, average diameter and biomass. The product will be prepared for areas of $2.5 \times 2.5 \mathrm{~km}$ [67] and produces DTMs with $1 \mathrm{~m}$ resolution.

DTW maps were prepared by the Swedish forest agency over the whole country since 2014 and were freely available through their online map services. The maps had been used by majority of forestry companies since about 5 years and contributed to improve planning of different forest operations [66].

A new version of soil moisture maps has been developed at the Swedish University of Agricultural Sciences (SLU) and is available at online map services of the Swedish forestry agency since beginning of 2021. There, Artificial Intelligence (AI) information from various (24) data layers, e.g. soil type, topography and climate, is combined to estimate a moisture index representing a yearly average of soil moisture in raster layers of $2 \times 2 \mathrm{~m}$ resolution [45•].

\section{Norway}

The Norwegian Mapping Authority (Kartverket), in conjunction with partner organizations, collects, systemizes, processes, manages and disseminates national geographical information. In 2016, a national programme was started to generate a new detailed terrain model based on ALS, for areas with vegetation/forest cover, and image matching for mountain areas with little to no vegetation. The new terrain model is scheduled to be completed for the whole country $\left(325,000 \mathrm{~km}^{2}\right)$ by 2022 [68]. Private vendors were awarded project wise to conduct the scanning campaigns with a coverage of at least $2 \mathrm{pts} / \mathrm{m}^{2}$, delivering classified point clouds to the Norwegian Mapping Authority. Classes vary between ALS projects but always include the class "ground points". In addition to the contracted deliveries, existing regional ALS data of higher quality, but also photogrammetric image matching for high mountain plateaus, is used by the Norwegian Mapping Authority to generate the latest national DTM. The density of the point cloud behind the updated national DTM can therefor regionally differ but is constantly updated if higher quality data is available. The latest data sets can be visualized with a variety of web map services at the portal "hoydedata.no". Both the ALS point cloud data and a $1 \mathrm{~m}$ resolution DTM can freely be downloaded. A 
second acquisition of a national ALS data set at a later point in time is not planned so far. The digital elevation data will be updated using photogrammetry based on aerial images that are acquired in regular intervals (5-10 years) [69].

Based on the DTM availability, two DTW maps (Markfuktighetskart) presenting the soil moisture in a grid either as classes or in centimetre towards the soil surface are openly available on national level (www.kilden.nibio.no). The DTW maps are to varying degree used by foresters in the planning of forest operations in Norway. Further developments of the DTW maps will include a dynamic approach for trafficability mapping that combines weather data and DTW maps to predict trafficability, which will also lead to a better seasonal classification of operational sites.

\section{France}

In 2021, the first national French ALS campaign was initiated by the National Institute of Geographic and Forest Information (IGN = public administrative establishment placed under the joint authority of the Ministries in charge of ecology and forestry). In the course of this campaign, 10 $\mathrm{pts} / \mathrm{m}^{2}$ based products will progressively be published as open data by 2025, starting from the Mediterranean region and upward [70]. Although no starting date finalized so far, it is supposed to be implemented with countrywide coverage over a period of 5 years. Yet, sub-regions are identified as priorities for EU CAP monitoring purpose and are expected to be accomplished by 2023 . The scanning campaign is envisaged to be conducted with a coverage of $10 \mathrm{pts} / \mathrm{m}^{2}$, and the data will be used to produce DTMs and DSMs, after completion openly available through the national geoportal (https://www.geoportail.gouv.fr/). Additionally, an initiative from the Ministry of Agriculture intends to update the spatial data on 3-year intervals through $25 \mathrm{~cm}$ IR photography. But currently, the BD Alti, based on various regional data acquisition techniques, is the only nationwide available DTM, with highest resolution of $25 \mathrm{~m}$ grids, only.

For forest soil trafficability assessment, a model developed for agriculture (SoilFlex; developed by Keller et al. [71]) was also tested on two French forest sites. The purpose of the model was to predict compaction risks and rutting from a set of accessible parameters to practitioners for either agriculture or forestry. Results were, for the most part, successful. The exception occurred for the inclusion of the surface organic layer. This organic layer includes a high organic carbon and moisture and a smaller deformation than predicted by the model [72]. During the last decade, experimental plots were instrumented and monitored to document hydric transfer phenomena and forest soil reaction after compaction. Such fundamental research has been limited to few plots established on state-owned forest (two sites in Lorraine region) or via the network F-ORE-T with two sites partially focused on and instrumented for these topics. Monitoring of experimental sites for the long-term productivity shows that after two of the routing cycles of a forwarder, the sensitive forest soils are quickly degraded, and their restoration takes longer than 7 years [73]. Moreover, active restoration through e.g. mechanical loosening or ecological engineering practices such as exudation and providing substrates to promote biotic processes of soil recovery following soil compaction is difficult [74].

\section{Germany}

Owing to the federal organization in Germany, generation and provision of geodata is administered at different regional scales. The 16 individually organized state surveying offices of Germany are responsible for their respective data acquisition, including ALS campaigns to create terrain models. Although the resultant DTMs possess a high variability in terms of technology used and updating, they are available in all states with a grid cell size of $1 \mathrm{~m}$, since the completion of the state Saxony in 2020 [75]. Access and retail fees depend on individual policies, ranging from open data DTMs, as provided via a web coverage service for the area of North Rhine-Westphalia [76] to commercial products as available for the area of Lower Saxony [77].

The Federal Agency for Cartography and Geodesy, BKG (Bundesamt für Kartographie and Geodäsie), in fulfillment of the Federal Geo-data Reference Act (BGeoRG), maintains geodetic reference systems and collects and provides data for utilization by other national authorities and to fulfil its international obligations [78]. The BKG delineates and updates countrywide DTMs as soon as new data is submitted by one of the 16 state surveying offices. The state-wide DTMs are merged to countrywide DTMs with a grid cell size ranging from 5 to $1,000 \mathrm{~m}$. A countrywide DTM with a grid cell size of $200 \mathrm{~m}$ is openly accessible as part of the INSPIRE programme [64], same applies to the digital CORINE land cover map "LCL5", providing land-use classification at 5 ha resolution. DTMs with a higher resolution, covering the whole area of Germany, are retailed as commercial products by the BKG. Among these, the "DGM5" ( $5 \mathrm{~m}$ grid cell size) has the highest resolution, with prices dependent on area size and type of utilization.

Despite of the availability of DTMs, trafficability of forest management units in Germany is currently rather statically and non DTW-based evaluated, besides at a current regional research activity in North Rhine-Westphalia [79]. Site information and terrain slope classifications, in combination with the local forest manager's experience on trafficability, are a common way to select appropriate machine systems and schedule the most suited time of the forest operation. However, soil mapping has been conducted intensively in Germany, and digital soil maps are available, although 
highly varying between states [80]. Based on such soil maps, regional solutions were developed to support the common practice for mechanized forest operations. For instance, the state forest enterprise of Lower Saxony introduced trafficability risk maps, consisting of four risk levels [81] and made available for forestry stakeholders through an internal online GIS (geographic information system). Another approach was developed to evaluate operational systems according to technical limitations by the site classification, and in addition to observed stand development phases and weather conditions during the scheduled harvesting period [82]. Going a step further, the State Office for Environment, Agriculture, and Geology in the state of Saxony (LFULG) already provides a digital map showing soil's sensitivity to compaction at a scale of 1:50,000 [83]. It is based on the governmental digital soil map "digBK50", interfaced with monthly climatic water balance values recorded from 1993 onwards, and allows to consider soil compaction sensitivity according to various soil features during the seasons for large area planning, such as agricultural or construction operations. Although this is one of the first attempts of a soil moisturedriven trafficability modelling, the scale is too large to suit individual forestry operations.

\section{Austria}

Based on the INSPIRE programme of the European Parliament [63], and legally ratified through [84], a DTM with a grid cell size of $10 \mathrm{~m}$ is openly accessible for the whole area of Austria. This DTM has been retrieved from the first cycle of scan flights by ALS, in 2013. Due to the country's federalism, the geospatial data are managed individually by the nine states. A second and third cycle was performed by each state independently. The data density for the first cycle, in general, was $4 \mathrm{pts} / \mathrm{m}^{2}$, while the intended value for ongoing measurements was $8-16 \mathrm{pts} / \mathrm{m}^{2}$.

Austria has an open geodata portal, operated by the governmental provider [85]. The availability of geospatial data varies between the states: For instance, in Upper Austria, all the data are made freely available by the state office and contain DTMs with a grid cell size of $0.5 \mathrm{~m}$ or $1 \mathrm{~m}$ for each municipality. A guidance for merging and processing the $\mathrm{XYZ}$ tiles, using open tools, is provided too [86]. In line with this data organization, several Austrian states openly provide DTMs with a grid cell size of $1 \mathrm{~m}$. However, for the area of Burgenland, Tyrol or Lower Austria, freely accessible DTMs show a lower grid cell size $(5 \mathrm{~m}$, or $10 \mathrm{~m})$. For the area of Vorarlberg, contour lines are available only, either as a shapefile or rasterized.

Although the DTMs available for a large area of Austria are sufficient and the country declared a mandatory conservation of soils [87, 88], an implementation of machineinduced impacts through trafficability predictions is pending so far. Still, soil mappings and additional geospatial data for various topics such as forest, natural hazards, nature conservation, flood, and aerial images are offered partially.

\section{Poland}

In Poland, the data covering now whole country and first large acquisition is from one ALS campaign completed between 2011 and 2014. It was completed to fulfil obligations imposed on EU countries by the Directive 2007/60/EC of the European Parliament and the Council on the Assessment and Management of Flood Risks (23 October 2007) [89]. To assess flood risk, the Polish Government decided to start the project entitled "IT System for the Country's Protection Against Extraordinary Threats" (in Polish: ISOK - "Informatyczny System Osłony Kraju przed nadzwyczajnymi zagrożeniami”). Under this project, $92 \%$ of the total area was covered with ALS data, and based on DTM generated from ALS data, the flood risk assessment was determined. Before this period, there were obtained ALS data just from single projects and covered relatively small areas. The area scanned under the ISOK project was $288,806 \mathrm{~km}^{2}$, from which $267,403 \mathrm{~km}^{2}$ was completed with density of $4 \mathrm{pts} / \mathrm{m}^{2}$; $8,148 \mathrm{~km}^{2}$ with $6 \mathrm{pts} / \mathrm{m}^{2}$, priority areas; and $13,769 \mathrm{~km}^{2}$ with $12 \mathrm{pts} / \mathrm{m}^{2}$, cities [89]. The derived DTMs are available with a grid cell size of 0.5 and $1 \mathrm{~m}$. After 2014, new campaigns of ALS data acquisition were carried out, and now almost whole Poland is covered at least with one ALS data set.

The authority which hosts the national data is the Department of Photogrammetry at the Geodesic and Cartographic Documentation Centre in Warsaw. All data are freely available for any purpose. But currently the data has not been used to implement a DTW or other spatial approach to predict forest trafficability. However, on a pilot site, DTW maps have recently been applied for trafficability prediction on research level [79].

\section{Latvia}

In Latvia, $50.1 \%$ of the territory is covered by forests; agricultural land is covering $22.8 \%$, grasslands $15.9 \%$, wetlands $6.2 \%$ and settlements $4.8 \%$ [90]. One-time coverage of ALS data is provided for the whole territory of the country, and data collection has been organized by the Latvian Geospatial Information Agency (LGIA) by hiring foreign companies. ALS surveys were performed in the period from 2013 to 2019. The Leica ALS70, Riegl LMS-Q680i and Riegl LMSQ780i scanners were used for scanning. ALS scanning was performed on both the leaf-on and leaf-off periods. The total point density is at least 4 points per square meter, while the density of ground points is at least 1.5 points per square meter. The ALS point cloud is automatically classified by ground points, as well as low, medium and high vegetation 
classes, but infrastructure and other objects are manually classified. The data is freely available on the LGIA website, as well as a generated DTM of $20 \mathrm{~m}$ resolution. Negotiations are underway for a second ALS campaign.

At the beginning of 2021, ALS data in Latvia were used to generate DTW maps nationwide in $5 \mathrm{~m}$ horizontal resolution, and individual map sheets can be downloaded from the LSFRI Silava website (http://www.silava.lv/produkti/Karto grafiskie-materiali.aspx). In parallel, work is underway to develop a wet area map for the entire country according to the methodology described by Ivanovs and Lupikis [91]. Wet area mapping uses various indices obtained by processing DTM, such as depression maps, normalized elevation index, slope, TWI, DTW and other indices. These maps are planned to be popularized in forestry industry seminars and put into practice in forest management planning.

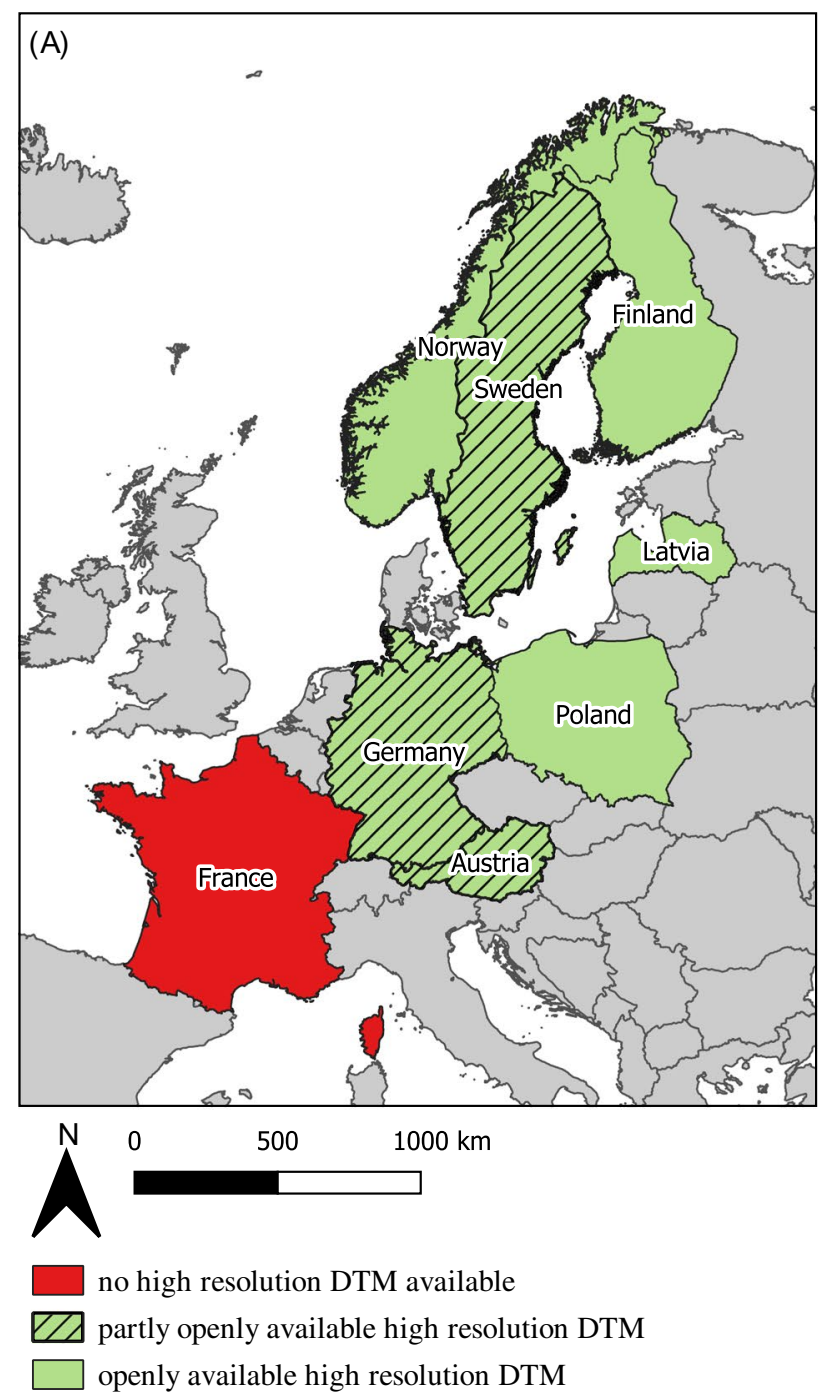

\section{Discussion}

This review indicated that there is a potential to mitigate impacts from ground-based harvesting by improved planning aided by DTW-derived predictions of sensitive soil conditions. The review of the country-wise status of trafficability predictions illustrated that basic requirements for applications in forestry industry are expanding throughout Northern and Central Europe with the increasing availability of highly accurate ALS-derived DTMs (Fig. 2A). However, it is merely in the Nordic countries that national DTW maps are publicly available with close to national coverage (Fig. 2B).

Since most European countries have initiated national ALS flight campaigns, country- or state-wide DTMs are available, enabling the creation of DTW maps for practical and scientific purposes. The creation of countrywide DTW

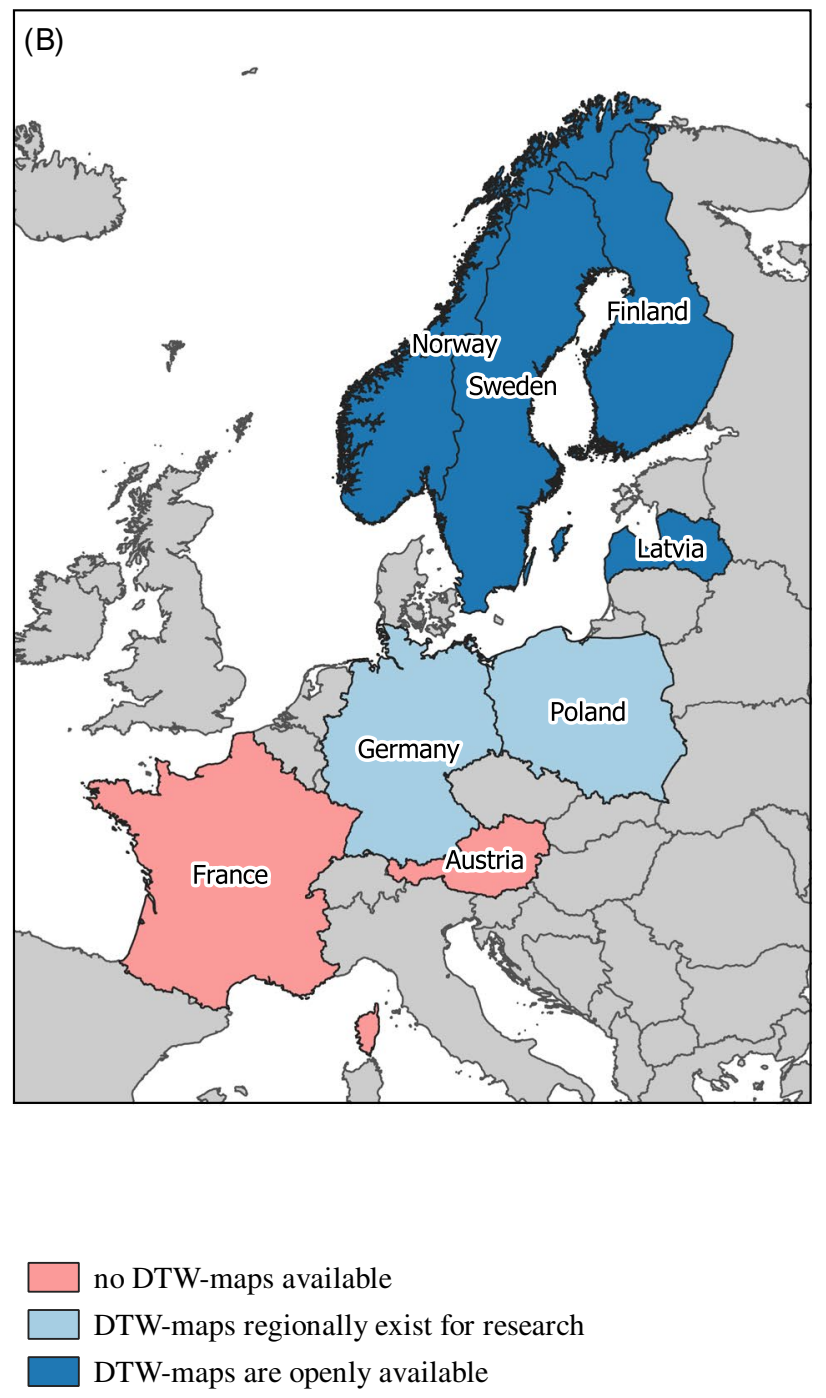

Fig. 2 Availability and accessibility of A high-resolution digital terrain models (DTM) and B depth-to-water (DTW) maps among the European countries included in the review about current state of trafficability prediction 
maps has already been facilitated by specific public or private institutions in the Nordic countries such as Sweden, Norway, Finland, and Latvia. In order to actually enable the widespread use of high-resolution DTW maps in forest operations, the maps will very likely have to be produced by a central organization as it seems unrealistic that small- and medium-sized individual organizations are able to execute the acquisition of openly available data or the commercial purchase of DTMs from governmental providers. The availability of DTMs ranges between openly accessible DTMs with a grid cell size of $0.5 \mathrm{~m}$ to complex hybrid business models requiring the purchase of DTMs with such a high spatial resolution. For instance, in the case of large areas of Austria and Germany, a fee is required for high-resolution DTMs. There, only DTMs with a grid cell size of $5 \mathrm{~m}, 10 \mathrm{~m}$ or $200 \mathrm{~m}$, respectively, are made openly accessible according to the INSPIRE programme [64]. Although the application of the DTW algorithm is generally robust to DTMs of different size [54], best results are achieved with DTM resolutions not exceeding 5-10 m, and ideally be even less than $5 \mathrm{~m}$ [92]. Thus, DTW modelling is technically also possible on DTMs with a low resolution of e.g. $200 \mathrm{~m}$, but the resulting DTW map would not be practical for operational implementation to determine machine trafficability on a logging site [54].

Generally, it can be stated that the availability and accessibility of high-resolution DTMs is not a major limitation for the creation of DTW maps anymore. All surveyed countries already provide DTMs with a sufficient resolution, or as in the case of France, are on the way to facilitate national ALS campaigns. The more fundamental bottleneck might be the actual calculation of the DTW algorithm for the application of such maps as tools to increase soil conservation. Currently, DTW maps in most countries are produced by researchers and individual authorities [54] for an intended user, who covers the costs or possesses specific project funds. For a widespread practical application, supporting day-to-day forest operations, the maps should be generated on behalf of forestry stakeholders by dedicated experts, since entrepreneurs might not have the capability to create DTW maps. Although not solely DTW-based, the currently available static trafficability maps in Finland are a good example how information about trafficability can be made openly accessible and support sustainable forest operations at small scale [65]. Another big asset of the Finish maps is also the classification according to seasonal recommendations for the execution of operations [65]. Such a feature current DTW maps are generally lacking, since they just define an area as "wet" or "dry" [45•], although attempts to further classifications into various wetness categories are in progress [66]. Therefore, it would be a worthwhile endeavour to governmentally provide comprehensive trafficability maps, covering European forests. In addition, the open accessibility to
DTMs with a sufficient resolution as well as to remaining geospatial data would support and promote both practical applications and purposes, as confirmed by Melander et al. [17].

Regardless of the origin of DTW maps, an enhanced soil conservation through cartographic material requires a userspecific interface. Modern forest machines are capable to read and display geospatial grids, such as DTW maps. Apart from that, the "TECH4EFFECT Mapping App" [93] is a good example following the open geospatial information philosophy, by providing such an interface through a nocost Android OS mobile application. The app is conceived primarily as a visualization tool for machine operators to be able to adopt their path of travel in accordance with the geo-referenced location and displayed DTW maps. Additionally, such apps usually allow for incorporating further spatial information about additional "no-go areas", such as protected areas, with the option to prompt the user with a signal when approaching these.

Displaying DTW maps by machine's on-board computers, integrated into mobile GIS applications, can provide the operator with site-specific information to choose the extraction route that combines consideration for both benefits for soil conservation and operational efficiency. The latest GNSS (Global Navigation Satellite System) receivers are standard features on state-of-the-art logging equipment, setting the basis for such an approach. Yet, precise machine positioning, as through RTK (real-time kinematic) support [94], and in-field access to DTW maps, which could be provided as web map service, require mobile networks with high data transmission standards, also in remote forest areas [95]. But in many European regions, the mobile network infrastructure does not meet these requirements yet [96]. It is therefore the responsibility of the relevant government agencies of the individual countries to build up the demanded standards. Until then, standalone applications, functioning in off-line modes, will be the focus of intermediate solutions [95].

Besides technical and administrative challenges, a fullrange implementation of DTW-based trafficability maps would require a dynamic approach, accounting for seasonal variation of soil moisture [92, 97, 98]. Research activities currently address this issue, for example by sequential combination of DTW maps and additional, freely accessible weather data. This led to a recently conducted dynamic approach, integrating information about topography, soil and vegetation [99], used for trafficability prediction on pilot sites in Finland, creating suitable outputs with a grid cell size of $16 \mathrm{~m} \mathrm{[46 \bullet \bullet ].} \mathrm{Including} \mathrm{real-time} \mathrm{weather} \mathrm{forecasts}$ in the trafficability models would further enhance prediction quality at a dynamic level $[92,97,98]$.

Further to dynamic information about moisture-driven trafficability, operational information is required to optimize 
quasi-instantaneous planning, the actual most efficient routing of forestry equipment to ensure productive operations with minimal impact. The "BestWay" decision support system [60•] shows on a case study level in Sweden how DTW maps, in combination with further detailed information on operational site features, can be used for optimized routing. Detailed information on forest volume, its density and concentration, position of landings and areas for natural conservation, as well as known unavoidable crossings in the terrain, are used in complementing the DTW maps. By this, the least cost extraction route with lowest expectable soil damage can be identified. Despite its promising results, evaluated under scientific settings, the "BestWay" system is too complex and processing capacity demanding for practical applications [45•]. However, principles of the "BestWay" decision system have been adapted to develop the more basic but operational commercial planning tool "Timbertrail", which is well acknowledged by first user experiences [100]. This pinpoints on the relevance to further implement additional spatial and site-specific information to reach sufficient trafficability prediction systems.

Site-specific information, such as information derived from forest inventories or soil mapping, are commonly gathered by national institutions, but not always openly accessible for every forestry stakeholder. National forest inventories were initiated in Europe already a century ago, providing detailed information on the forest condition and other related parameters for decision support, collected through sample plots, but also remote sensing approaches, continuously improving on the fine resolution of this data [101]. In addition, soil mapping on national level has a long tradition in Europe too, and initiatives are in place to merge national attempts to a digital and thematic soil map database-yet this is a long-term process, and the resulting spatial information will only be available at a coarse resolution [102]. The accessibility to various geospatial data gathered by national authorities and consequently the ability to integrate such data in topical trafficability predictions should be improved by open access databases.

Current research demonstrated already how openly available geospatial and temporal data can be used to improve predictions of soil moisture and trafficability. Recent findings of Schönauer et al. [103] showed a method how information of different origins and spatial resolutions was fused, in order to achieve a spatiotemporal prediction of soil moisture on different forest sites in Europe. Moreover, spatial predictive systems can be merged with operationspecific information, captured in real-time through forestry machine-based sensors itself $[17,45 \bullet, 46 \bullet \bullet]$. Fully mechanized harvesting operations are eminently suitable for such an approach, since the forwarder extraction is invariably consecutive to the harvester traffic, allowing forwarder routing to be adapted based on the previously captured data. The international forest machine standard StanForD compiles operational data for various components of forest machines and can be used to determine the felled and loaded timber on each machine; thus, the pile volumes can be constantly updated as well as the gross weight of the vehicle. In addition, the CAN-bus (controller area network) system captures data from the engine and drive train, which are valuable for trafficability purposes, too. As soon as telecommunication infrastructure will allow for improvements of accurate RTKsupported positional data from the GNSS, wheel slip can potentially be computed [104], based on machine internal CAN-bus recordings [16•]. The CAN-bus data therefore can contribute to computationally producing a mobility map for optimal routing of the forwarder, as rut formation after a harvester pass has been a good predictor of the rut formation in forwarding, both on mineral and on peatland soils [41, 105]. In addition, forest machine-mounted LiDAR (light detecting and ranging) proved to be able to measure rut development during forwarder operations and can be used as another potential component to be integrated in an active routing system of a forwarder $[17,45 \bullet, 46 \bullet \bullet, 106]$.

With GIS expertise nowadays in place in forestry institutional and corporate settings, and the DTW algorithm available through open access data repositories [56], the corresponding maps can be easily created for regional applications, as long as access to a sufficient DTM is granted. Thus, the required economic resources can be considered moderate in comparison to the benefits of improved operational planning and increased efficiency during timber harvesting. Moreover, since static DTW maps once created can easily be used on mobile devices or standard forest machine map interfaces, no further running costs can be expected. Yet, further developments towards a dynamic approach could demand additional services and system infrastructure related to the more intensive data input, which can add new costs to the use of such systems. However, any potential additional expenses should always be offset against the multiple environmental benefits associated to higher consideration of soil conservation along the timber supply chain. Further, it is also worth mentioning that DTW maps can support multiple other application areas in forestry. DTW maps were reported as being promising tools in enhancing water protection through a better spatial knowledge of perennial and intermittent streams, an important asset for the implementation of riparian buffer zones as best management practice among sustainable forest operations [107]. Even in winter months, when the surface was covered by snow, and streams were invisible, such maps helped to avoid machine passes in these sensitive areas [108, 109]. Further, Bartels et al. [110] used DTW maps to relate bryophyte assemblages to wet forest areas, indicating the potential use of the algorithm to select between harvest areas and sites relevant for biodiversity 
conservation within a landscape management approach. In addition, DTW maps were recently used to monitor site indices. A variation in productivity was adequately portrayed in a survey by Bjelanovic et al. [111], who reported a potential application to model forest growth and yield. Finally, a combination of DTW maps with data of annual precipitation was used to delineate drought-prone areas during periods of low moisture conditions $[108,109,112]$.

\section{Conclusions}

DTW maps are eligible to support forest management towards a mitigation of traffic-induced soil impacts, by identifying sensitive areas that should be avoided during mechanized operations. It is therefore supportive during the planning phase, but also during the execution of operations. The creation of practicable DTW maps relies on the availability of high-resolution DTMs. Most of the European countries have programmes to capture ALS data and produce highresolution DTMs with increasing data quality or are on the way to do so. However, the DTMs and other spatial information is not always openly available, or just in lower resolutions. In order to generate and apply DTW-based trafficability maps to aim for sustainable forest operations on a wider range, the already proceeding European open access policy for spatial data should be further intensified and be more consolidated across the continent. This should not only cover spatial terrain data, but also forest inventory, soil mapping, climatic conditions and other relevant information currently envisaged to further improve upon the potential of dynamic trafficability mapping and post-harvest impact monitoring. Furthermore, additional work is needed to integrate this information through consistent applications and interfaces to enable a full usage of such systems by forest planners and machine operators. Despite all that, DTW maps already found their way into forest operations and first attempts to make them dynamic are in place. The Nordic countries, in particular Sweden, adopt a forerunner position, but the other reviewed countries initiate similar approaches, and it can be expected that in foreseeable time, dynamic trafficability maps will become a standard tool to support sustainable forest operation practices.

Funding Open access funding provided by Norwegian Institute of Bioeconomy Research. This research was funded by the Bio Based Industries Joint Undertaking under the European Union's Horizon 2020 research and innovation programme, TECH4EFFECT Knowledge and Technologies for Effective Wood Procurement-project (grant number 720757) and EFFORTE Efficient forestry by precision planning and management for sustainable environment and cost-competitive bio-based industry—project (grant number 720712). The contributions from the University of Göttingen were further financially supported by the Eva Mayr-Stihl Stiftung.

\section{Declarations}

Conflict of Interest Stephan Hoffmann, Marian Schönauer, Joachim Heppelmann, Antti Asikainen, Emmanuel Cacot, Benno Eberhard, Hubert Hasenauer, Janis Ivanovs, Dirk Jaeger, Andis Lazdins, Sima Mohtashami, Tadeusz Moskalik, Tomas Nordfjell, Krzysztof Stereńczak, Bruce Talbot, Jori Uusitalo, Morgan Vuillermoz and Rasmus Astrup declare that there are no conflicts of interest to declare.

Human and Animal Rights and Informed Consent This article does not contain any studies with human or animal subjects performed by any of the authors.

Open Access This article is licensed under a Creative Commons Attribution 4.0 International License, which permits use, sharing, adaptation, distribution and reproduction in any medium or format, as long as you give appropriate credit to the original author(s) and the source, provide a link to the Creative Commons licence, and indicate if changes were made. The images or other third party material in this article are included in the article's Creative Commons licence, unless indicated otherwise in a credit line to the material. If material is not included in the article's Creative Commons licence and your intended use is not permitted by statutory regulation or exceeds the permitted use, you will need to obtain permission directly from the copyright holder. To view a copy of this licence, visit http://creativecommons.org/licenses/by/4.0/.

\section{References}

Papers of particular interest, published recently, have been highlighted as:

- Of importance

$\bullet$ Of major importance

1. Cambi M, Certini G, Neri F, Marchi E. The impact of heavy traffic on forest soils: a review. For Ecol Manage. 2015;338:124-38. https://doi.org/10.1016/j.foreco.2014.11.022.

2. Horn R, Vossbrink J, Peth S, Becker S. Impact of modern forest vehicles on soil physical properties. For Ecol Manage. 2007;248:56-63. https://doi.org/10.1016/j.foreco.2007.02.037.

3. Agherkakli B, Najafi A, Sadeghi SH. Ground based operation effects on soil disturbance by steel tracked skidder in a steep slope of forest. J For Sci. 2010;56:278-84. https://doi.org/10. 17221/93/2009-JFS.

4. Ampoorter E, Verheygen K, Hermy M, editors. Soil damage after mechanized harvesting: results of a meta-analysis. Morgantown; 2009.

5. Gerasimov Y, Katarov V. Effect of bogie track and slash reinforcement on sinkage and soil compaction in soft terrains. Croat J For Eng. 2010;31:35-45.

6. Labelle ER, Jaeger D. Soil compaction caused by cut-to-length forest operations and possible short-term natural rehabilitation of soil density. Soil Sci Soc Am J. 2011;75:2314-29. https://doi. org/10.2136/sssaj2011.0109.

7. Crawford LJ, Heinse R, Kimsey MJ, Page-Dumroese DS. Soil sustainability and harvest operations. General Technical Report RMRS. 2021. https://doi.org/10.2737/RMRS-GTR-421. 
8. Mattila U, Tokola T. Terrain mobility estimation using TWI and airborne gamma-ray data. J Environ Manage. 2019;232:531-6. https://doi.org/10.1016/j.jenvman.2018.11.081.

9. Uusitalo J, Ala-Ilomäki J, Lindeman H, Toivio J, Siren M. Predicting rut depth induced by an 8-wheeled forwarder in finegrained boreal forest soils. Ann For Sci. 2020;77:42. https://doi. org/10.1007/s13595-020-00948-y.

10. Šušnjar M, Horvat D, Šešelj J. Soil compaction in timber skidding in winter conditions. Croat J For Eng. 2006;27:3-15.

11. Gabbert CC, Gazal K, McNeel J. Economic contributions of West Virginia's forest products industry over time: a look at 2006, 2010, 2015, and 2017 data. For Pro J. 2020;70:200-12. https://doi.org/10.13073/FPJ-D-19-00052.

12. Climate Service Center Germany (GERICS). Remo-RCM REMO UBA. 2020. c. Accessed 7 Feb 2020.

13. Uusitalo J, Salomäki M, Ala-Ilomäki J. Variation of the factors affecting soil bearing capacity of ditched pine bogs in Southern Finland. Scand J For Res. 2015;30:1-11. https://doi.org/10.1080/ 02827581.2015.1012110.

14. Rab M. Recovery of soil physical properties from compaction and soil profile disturbance caused by logging of native forest in Victorian Central Highlands. Australia For Ecol Manage. 2004;191:329-40. https://doi.org/10.1016/j.foreco.2003.12.010.

15. Schweier J, Magagnotti N, Labelle ER, Athanassiadis D. Sustainability impact assessment of forest operations: a review. Curr For Rep. 2019;5:101-13. https://doi.org/10.1007/ s40725-019-00091-6.

16. Ala-Ilomäki J, Salmivaara A, Launiainen S, Lindeman H, Kulju S, Finér L, et al. Assessing extraction trail trafficability using harvester CAN-bus data. Int J For Eng. 2020;31:138-45. https://doi.org/10.1080/14942119.2020.1748958. (The study highlights on how forest machines itself can contribute to trafficability prediction for subsequent machines through internal data capturing (e.g. CAN-bus system) in order to further progress towards an dynamic approach of trafficability mapping.)

17. Melander L, Einola K, Ritala R. Fusion of open forest data and machine fieldbus data for performance analysis of forest machines. Eur J Forest Res. 2020;139:213-27. https://doi.org/ 10.1007/s10342-019-01237-8.

18. Startsev AD, McNabb DH. Effects of compaction on aeration and morphology of boreal forest soils in Alberta. Canada Can J Soil Sci. 2009;89:45-56. https://doi.org/10.4141/CJSS06037.

19. Startsev AD, McNabb DH. Effects of skidding on forest soil infiltration in west-central Alberta. Can J Soil Sci. 2000;80:61724. https://doi.org/10.4141/S99-092.

20. Arvidsson J, Sjöberg E, van den Akker JJ. Subsoil compaction by heavy sugarbeet harvesters in southern Sweden. Soil Tillage Res. 2003;73:77-87. https://doi.org/10.1016/S0167-1987(03) 00101-6.

21. Mariotti B, Hoshika Y, Cambi M, Marra E, Feng Z, Paoletti E, Marchi E. Vehicle-induced compaction of forest soil affects plant morphological and physiological attributes: a meta-analysis. For Ecol Manage. 2020;462:118004. https://doi.org/10.1016/j. foreco.2020.118004.

22. DeArmond D, Ferraz JB, Higuchi N. Natural recovery of skid trails: a review. Can J For Res. 2021:1-14. https://doi.org/10. 1139/cjfr-2020-0419.

23. Beylich A, Oberholzer H-R, Schrader S, Höper H, Wilke B-M. Evaluation of soil compaction effects on soil biota and soil biological processes in soils. Soil Tillage Res. 2010;109:133-43. https://doi.org/10.1016/j.still.2010.05.010.

24. Ampoorter E, van Nevel L, de Vos B, Hermy M, Verheyen K. Assessing the effects of initial soil characteristics, machine mass and traffic intensity on forest soil compaction. For Ecol Manage.
2010;260:1664-76. https://doi.org/10.1016/j.foreco.2010.08. 002.

25. Eklöf K, Schelker J, Sørensen R, Meili M, Laudon H, von Brömssen C, Bishop K. Impact of forestry on total and methylmercury in surface waters: distinguishing effects of logging and site preparation. Environ Sci Technol. 2014;48:4690-8. https:// doi.org/10.1021/es404879p.

26. de Wit HA, Granhus A, Lindholm M, Kainz MJ, Lin Y, Braaten HFV, Blaszczak J. Forest harvest effects on mercury in streams and biota in Norwegian boreal catchments. For Ecol Manage. 2014;324:52-63. https://doi.org/10.1016/j.foreco.2014.03.044.

27. Nordfjell T, Björheden R, Thor M, Wästerlund I. Changes in technical performance, mechanical availability and prices of machines used in forest operations in Sweden from 1985 to 2010. Scand J For Res. 2010;25:382-9. https://doi.org/10.1080/ 02827581.2010 .498385$.

28. Nordfjell T, Öhman E, Lindroos O, Ager B. The technical development of forwarders in Sweden between 1962 and 2012 and of sales between 1975 and 2017. Int J For Eng. 2019;30:1-13. https://doi.org/10.1080/14942119.2019.1591074.

29. Arvidsson J, Keller T. Soil stress as affected by wheel load and tyre inflation pressure. Soil Tillage Res. 2007;96:284-91. https://doi.org/10.1016/j.still.2007.06.012.

30. Labelle ER, Jaeger D. Effects of steel flexible tracks on forwarder peak load distribution: results from a prototype load test platform. Croat J For Eng. 2019;40:1-23.

31. Edlund J, Keramati E, Servin M. A long-tracked bogie design for forestry machines on soft and rough terrain. J Terramech. 2013;50:73-83. https://doi.org/10.1016/j.jterra.2013.02.001.

32. Starke M, Derron C, Heubaum F, Ziesak M. Rut depth evaluation of a triple-bogie system for forwarders-field trials with TLS data support. Sustain. 2020;12:6412. https://doi.org/10. 3390/su12166412.

33. Fjeld D, Østby-Berntsen $\varnothing$. The effects of an auxiliary axle on forwarder rut development - a Norwegian field study. Int J For Eng. 2020;31:192-6. https://doi.org/10.1080/14942119.2020. 1765645

34. Engler B, Hoffmann S, Zscheile M. Rubber tracked bogieaxles with supportive rollers - a new undercarriage concept for log extraction on sensitive soils. Int J For Eng. 2021;32:43-56. https://doi.org/10.1080/14942119.2021.1834814.

35. Seixas F, McDonald T. Soil compaction effects of forwarding and its relationship with 6- and 8-wheel drive machines. For Prod J. 1997;47:46-52.

36. Schönauer M, Holzfeind T, Hoffmann S, Holzleitner F, Hinte B, Jaeger D. Effect of a traction-assist winch on wheel slippage and machine induced soil disturbance in flat terrain. Int J For Eng. 2021;32(SUP1):1-11. https://doi.org/10.1080/14942119. 2021.1832816.

37. Labelle ER, Jaeger D, Poltorak. Assessing the ability of hardwood and softwood brush mats to distribute applied loads. Croat J For Eng. 2015;36:227-42.

38. Li W, Kang F. Design and analysis of steering and lifting mechanisms for forestry vehicle chassis. Math Probl Eng. 2020;5971746:1-16. https://doi.org/10.1155/2020/5971746.

39. Schönauer M, Hoffmann S, Maack J, Jansen M, Jaeger D. Comparison of selected terramechanical test procedures and cartographic indices to predict rutting caused by machine traffic during a cut-to-length thinning-operation. Forests. 2021;12:113. https://doi.org/10.3390/f12020113.

40. Jones M-F, Arp PA. Relating cone penetration and rutting resistance to variations in forest soil properties and daily moisture fluctuations. Open J Soil Sci. 2017;07:149-71. https://doi. org/10.4236/ojss.2017.77012. 
41. Sirén M, Salmivaara A, Ala-Ilomäki J, Launiainen S, Lindeman $\mathrm{H}$, Uusitalo J, et al. Predicting forwarder rut formation on fine-grained mineral soils. Scand J For Res. 2019;34:145-54. https://doi.org/10.1080/02827581.2018.1562567.

42. Uusitalo J, Ala-Ilomäki J, Lindeman H, Toivio J, Siren M. Modelling soil moisture - soil strength relationship of finegrained upland forest soils. Silva Fenn. 2019;59:10050. https:// doi.org/10.14214/sf.10050.

43. O’Sullivan M, Henshall J, Dickson J. A simplified method for estimating soil compaction. Soil Tillage Res. 1999;49:325-35. https://doi.org/10.1016/S0167-1987(98)00187-1.

44. Canillas EC, Salokhe VM. A decision support system for compaction assessment in agricultural soils. Soil Tillage Res. 2002;65:221-30. https://doi.org/10.1016/S0167-1987(02) 00002-8.

45.• Lidberg W, Nilsson M, Ågren A. Using machine learning to generate high-resolution wet area maps for planning forest management: a study in a boreal forest landscape. Ambio. 2020;49:475-86. https://doi.org/10.1007/s13280-019-011969. (The paper shows how soil features, namely moisture, recorded during national forest inventory data collection, can be used through machine learning approaches to create static maps for trafficability prediction as a planning tool.)

46.• Salmivaara A, Launiainen S, Perttunen J, Nevalainen P, Pohjankukka J, Ala-Ilomäki J, et al. Towards dynamic forest trafficability prediction using open spatial data, hydrological modelling and sensor technology. Forestry. 2020;93:662-74. https://doi.org/10.1093/forestry/cpaa010. (The study demonstrates a dynamic trafficability prediction framework, consisting of a hydrological model and a wide range of available spatial data. Further, the authors outline on the possibilities how dynamic trafficability maps could be implemented on national level in , based on continuous data flow, process-based modelling, and machine learning.)

47. Beven KJ, Kirkby MJ. A physically based, variable contributing area model of basin hydrology / Un modèle à base physique de zone d'appel variable de l'hydrologie du bassin versant. Hydrol Sci Bull. 1979;24:43-69. https://doi.org/10.1080/ 02626667909491834.

48. Seibert J, Bishop K, Nyberg L. A test of the TOPMODEL's ability to predict spatially distributed groundwater levels. Hydrol Processes. 1997;11:1131-44.

49. Sørensen R, Seibert J. Effects of DEM resolution on the calculation of topographical indices: TWI and its components. J Hydrol. 2007;347:79-89. https://doi.org/10.1016/j.jhydrol. 2007.09.001.

50. Grabs T, Seibert J, Bishop K, Laudon H. Modeling spatial patterns of saturated areas: a comparison of the topographic wetness index and a dynamic distributed model. J Hydrol. 2009;373:1523. https://doi.org/10.1016/j.jhydrol.2009.03.031.

51. Murphy PNC, Ogilvie J, Arp P. Topographic modelling of soil moisture conditions: a comparison and verification of two models. Eur J Soil Sci. 2009;60:94-109. https://doi.org/10.1111/j. 1365-2389.2008.01094.x.

52. Murphy PN, Ogilvie J, Meng F-R, White B, Bhatti JS, Arp PA. Modelling and mapping topographic variations in forest soils at high resolution: a case study. Ecol Modell. 2011;222:2314-32. https://doi.org/10.1016/j.ecolmodel.2011.01.003.

53. Vega-Nieva DJ, Murphy PNC, Castonguay M, Ogilvie J, Arp PA. A modular terrain model for daily variations in machine-specific forest soil trafficability. Can J Soil Sci. 2009;89:93-109. https:// doi.org/10.4141/CJSS06033.

54. Ågren AM, Lidberg W, Strömgren M, Ogilvie J, Arp PA. Evaluating digital terrain indices for soil wetness mapping - a Swedish case study. Hydrol Earth Syst Sci. 2014;18:3623-34. https://doi. org/10.5194/hess-18-3623-2014.
55. Murphy PNC, Ogilvie J, Castonguay M, Connors T, Meng FR, Arp PA. DEM-derived flow channel and wet area mapping: a new tool for forest operations planning. In: Sustainable Forest Management Network, University of Alberta, editor. Sustaining Canada's Forests: Building Momentum; June 20-22, 2006; Edmonton, Alberta, Canada; 2006.

56. Schönauer M, Maack J. R-code for calculating depth-to-water (DTW) maps using GRASS GIS: Zenodo; 2021. https://doi.org/ 10.5281/zenodo.5718133.

57. McNabb DH, Startsev AD, Nguyen H. Soil wetness and traffic level effects on bulk density and air-filled porosity of compacted boreal forest soils. Soil Sci Soc Am J. 2001;65:1238-47. https:// doi.org/10.2136/sssaj2001.6541238x.

58. Mohtashami S, Eliasson L, Jansson G, Sonesson J. Influence of soil type, cartographic depth-to-water, road reinforcement and traffic intensity on rut formation in logging operations: a survey study in Sweden. Silva Fenn. 2017;51:2018. https://doi.org/10. 14214/sf.2018.

59. Zimbelman EG, Keefe RF. Real-time positioning in logging: effects of forest stand characteristics, topography, and line-ofsight obstructions on GNSS-RF transponder accuracy and radio signal propagation. PLoS ONE. 2018;13:e0191017. https://doi. org/10.1371/journal.pone.0191017.

60.• Flisberg P, Rönnqvist M, Willén E, Frisk M, Friberg G. Spatial optimization of ground-based primary extraction routes using the BestWay decision support system. Can J For Res. 2021;51:67591. https://doi.org/10.1139/cjfr-2020-0238. (Through a comprehensive case study, the authors demonstrate the efficiency gains of using the decision support system BestWay, which incorporates depth-to-water maps, digital terrain data and forest volume density, as well as other operation restricting information available to planners. The study proofs that decision support systems like BestWay allow faster planning, ensure shorter driving distances, and reduce the impact on soil and water.)

61. Willén E, Hannson L. Mistra Digital Forest. Stockholm; 20.05.2021.

62. Li Z-L, Leng P, Zhou C, Chen K-S, Zhou F-C, Shang G-F. Soil moisture retrieval from remote sensing measurements: current knowledge and directions for the future. Earth Sci Rev. 2021;218:103673. https://doi.org/10.1016/j.earscirev.2021. 103673.

63. European Parliament. DIRECTIVE 2007/2/EC of the European Parliament and of the Council of 14 March 2007 Establishing an Infrastructure for Spatial Information in the European Community (INSPIRE).; 2007.

64. European Commission. INSPIRE. 2021. https://inspire.ec. europa.eu/about-inspire/563. Accessed 25 May 2021.

65. Kankare V, Luoma V, Saarinen N, Peuhkurinen J, Holopainen M, Vastaranta M. Assessing feasibility of the forest trafficability map for avoiding rutting - a case study. Silva Fenn. 2019;53:10197. https://doi.org/10.14214/sf.10197.

66. Ågren AM, Larson J, Paul SS, Laudon H, Lidberg W. Use of multiple LIDAR-derived digital terrain indices and machine learning for high-resolution national-scale soil moisture mapping of the Swedish forest landscape. Geoderma. 2021;404:115280. https://doi.org/10.1016/j.geoderma.2021.115280.

67. Lantmäteriet. Produktbesriving GSD-Höjddata, grid 2+. 2020. https://www.lantmateriet.se/globalassets/kartor-och-geografiskinformation/hojddata/hojd2_plus_2.8.pdf. Accessed 18 Nov 2021

68. Midtbø T. Cartographic Activities in Norway 2015-2019. Tokyo; 2019.

69. Kartverket. Program for omløpsfotografering [Orbital Photography Program]. 2021. https://kartverket.no/geodataarbeid/progr am-for-omlopsfotografering. Accessed 15 Aug 2021 
70. IGN. Programme Lidar HD: vers une cartographie 3D du territoire. Saint-Mande, Cadex; 09.07.2021.

71. Keller T, Défossez P, Weisskopf P, Arvidsson J, Richard G. SoilFlex: a model for prediction of soil stresses and soil compaction due to agricultural field traffic including a synthesis of analytical approaches. Soil Tillage Res. 2007;93:391-411. https://doi.org/ 10.1016/j.still.2006.05.012.

72. Goutal N, Renault P, Ranger J. Forwarder traffic impacted over at least four years soil air composition of two forest soils in northeast France. Geoderma. 2013;193-194:29-40. https://doi. org/10.1016/j.geoderma.2012.10.012.

73. Goutal-Pousse N, Bonnaud P, Demaison J, Nourrisson G, George $\mathrm{P}$, Ranger J. Soil compaction on two sensitive sites in north-eastern France and natural or assisted recovery processes. In: Forest Mechanization (FORMEC), editor. Forest engineering: propelling the forest value chain; September 23-26, 2014; Gerardmer, France. Vienna; 2014.

74 Meyer C, Lüscher P, Schulin R. Recovery of forest soil from compaction in skid tracks planted with black alder (Alnus glutinosa (L.) Gaertn.). Soil Tillage Res. 2014;143:7-16. https://doi. org/10.1016/j.still.2014.05.006.

75. Arbeitsgemeinschaft der Vermessungsverwaltungen der Länder der Bundesrepublik Deutschland (AdV). ATKIS®-Digitale Geländemodelle. 2021. http://www.adv-online.de/AdV-Produ kte/Geotopographie/Digitale-Gelaendemodelle/. Accessed 09 Jan 2021

76. Bezirksregierung Köln. Digitales Geländemodell DGM1 WCS. 2020. https://www.bezreg-koeln.nrw.de/brk_internet/geobasis/ hoehenmodelle/digitale_gelaendemodelle/gelaendemodell/ index.html. Accessed 12 Sep 2020

77. Landesamt für Geoinformationen und Landesvermessung Niedersachsen (LGLN). Digitale Geländemodelle (DGM). 2020. https://www.lgln.niedersachsen.de/startseite/geodaten_karten/ 3d_geobasisdaten/dgm/digitale-gelaendemodelle-dgm-143150. html. Accessed 12 Sep 2020

78. Bundesamt für Kartographie und Geodäsie (BKG). Tasks and Organization. 2017. https://www.bkg.bund.de/EN/About-BKG/ Tasks-and-Organization/tasks-and-organization.html. Accessed 18 May 2017. Accessed 12 Sep 2020

79. Schönauer M, Talbot B, Jaeger D. Terrain accessibility maps for 4 case study areas: TECH4EFFECT project report, unpublished; 2019.

80. Federal Institute for Geosciences and Natural Resources (BGR). BGR - soil information system. 13.11.2021. https://www.bgr. bund.de/EN/Themen/Boden/boden_node_en.html. Accessed 13 Nov 2021.

81. Niedersächsische Landesforsten (NLF). Bodenschutz bei der Holzernte in den Niedersächsischen Landesforsten. 2017. https:// www.landesforsten.de/wp-content/uploads/2018/06/merkblatt_ bodenschutz_apr_2017.pdf. Accessed 21 Aug 2020

82. Kuratorium für Waldarbeit und Forsttechnik e.V. (KWF). KWFThementage 2013: Umweltgerechte Bewirtschaftung nasser Waldstandorte. München: Deutscher Landwirtschaftverlag; 2013

83. Feldwisch N, Friedrich C. Schädliche Bodenverdichtug vermeiden. Dresden; 10.04.2016.

84. BMDW. Bundesministerium für Digitalisierung und Wirtschaftsstandort. Bundesgesetz über eine umweltrelevante Geodateninfrastruktur des Bundes (Geodateninfrastrukturgesetz - GeoDIG) StF: BGB1. I Nr. 14/2010 (NR: GP XXIV RV 400 AB 590 S. 53. BR: 8276 AB 8279 S. 781.) [CELEX-Nr. 32007L0002]: Gesamte Rechtsvorschrift für Geodateninfrastrukturgesetz; 2010.

85. Cooperation OGD Österreich. Open Data Österreich. 2021. https://www.data.gv.at/. Accessed 14 Jun 2021.

86. Land Oberösterreich. Land Oberösterreich - Digitales Geländemodell $50 \mathrm{~cm} / 1 \mathrm{~m}$ (XYZ). 2021. https://www.land-oberoester reich.gv.at/211787.htm. Accessed 14 Jun 2021.
87. Alpine convention. Übereinkommen zum Schutz der Alpen: Alpenkonvention; 1995.

88. Alpine convention. Protocol on the implementation of the alpine convention of 1991 in the domain of soil conservation: protocol on soil conservation; 16.10.1998.

89. Wężyk P. Podręcznik dla uczestników szkoleń z wykorzystaniem produktów LiDAR [Manual for participants in training with LiDAR products]. $2^{\text {nd }}$ ed. Warszawa: Główny Urząd Geodezji i Kartografii; 2015.

90. Krumsteds LL, Ivanovs J, Jansons J, Lazdins A. Development of Latvian land use and land use change matrix using geospatial data of National forest inventory. Agronomy Res. 2019;17:2295305. https://doi.org/10.15159/AR.19.195.

91. Ivanovs J, Lupikis A. Identification of wet areas in forest using remote sensing data. Agronomy Res. 2018;16:2049-55. https:// doi.org/10.15159/AR.18.192.

92. Schönauer M, Väätäinen K, Prinz R, Lindeman H, Pszenny D, Jansen M, et al. Spatio-temporal prediction of soil moisture and soil strength by depth-to-water maps. Int J Appl Earth Obs Geoin. 2021;105:102614. https://doi.org/10.1016/j.jag.2021. 102614.

93. Schönauer M. TECH4EFFECT. Mapping app - minimize site impact through improved planning and operations: Deliverable 4.3; 25.11.2019.

94. Noordermeer L, Sørngård E, Astrup R, Næsset E, Gobakken T. Coupling a differential global navigation satellite system to a cut-to-length harvester operating system enables precise positioning of harvested trees. Int J For Eng. 2021;32:119-27. https://doi.org/10.1080/14942119.2021.1899686.

95. Müller F, Jaeger D, Hanewinkel M. Digitization in wood supply - a review on how Industry 4.0 will change the forest value chain. Comput Electron Agric. 2019;162:206-18. https://doi. org/10.1016/j.compag.2019.04.002.

96. GSM Association. Mobile Network Coverage Maps. 2021. https://www.gsma.com/coverage/\#463. Accessed 15 Jun 2021.

97. Leach JA, Lidberg W, Kuglerová L, Peralta-Tapia A, Ågren A, Laudon $\mathrm{H}$. Evaluating topography-based predictions of shallow lateral groundwater discharge zones for a boreal lakestream system. Water Resour Res. 2017;53:5420-37.

98. Heiskanen J, Hallikainen V, Salmivaara A, Uusitalo J, Ilvesniemi H. Predictive models to determine fine soil fractions and organic matter from readily available soil and terrain data of soils under boreal forest. Geoderma Reg. 2020;20:e00251. https://doi.org/10.1016/j.geodrs.2019.e00251.

99. Launiainen S, Guan M, Salmivaara A, Kieloaho A-J. Modeling boreal forest evapotranspiration and water balance at stand and catchment scales: a spatial approach. Hydrol Earth Syst Sci. 2019;23:3457-80. https://doi.org/10.5194/hess-23-3457-2019.

100. Creative Optimization AB. Timbertrail - a new road in the forest with Timbertrail. 2021. https://creativeoptimization.se/ en/solutions/timbertrail/\#timbertrail. Accessed 03 Sep 2021

101. Breidenbach J, McRoberts RE, Alberdi I, Antón-Fernández C, Tomppo E. A century of national forest inventories - informing past, present and future decisions. For Ecosyst. 2021. https://doi.org/10.1186/s40663-021-00315-x.

102. Kristensen JA, Balstrøm T, Jones RJA, Jones A, Montanarella L, Panagos P, Breuning-Madsen H. Development of a harmonised soil profile analytical database for Europe: a resource for supporting regional soil management. Soil. 2019;5:289-301. https://doi.org/10.5194/soil-5-289-2019.

103. Schönauer M, Prinz R, Väätäinen K, Astrup R, Pszenny D, Lindeman H, Jaeger D. Spatio-temporal prediction of soil moisture using soil maps, topographic indices and NASA Earthdata. https://doi.org/10.5281/zenodo.5702454. 
104. Suvinen A, Saarilahti M. Measuring the mobility parameters of forwarders using GPS and CAN bus techniques. J Terramech. 2006;43:237-52. https://doi.org/10.1016/j.jterra.2005. 12.005 .

105. Sirén M, Ala-Ilomäki J, Lindeman H, Uusitalo J, Kiilo K, Salmivaara A, Ryynänen A. Soil disturbance by cut-to-length machinery on mid-grained soils. Silva Fenn. 2019;53:10134. https://doi.org/10.14214/sf.10134.

106. Salmivaara A, Miettinen M, Finér L, Launiainen S, Korpunen H, Tuominen S, et al. Wheel rut measurements by forest machinemounted LiDAR sensors - accuracy and potential for operational applications? Int J For Eng. 2018;29:41-52. https://doi.org/10. 1080/14942119.2018.1419677.

107. Picchio R, Jourgholami M, Zenner EK. Effects of forest harvesting on water and sediment yields: a review toward better mitigation and rehabilitation strategies. Curr Forestry Rep. 2021. https://doi.org/10.1007/s40725-021-00146-7.

108. Kuglerová L, Ågren A, Jansson R, Laudon H. Towards optimizing riparian buffer zones: ecological and biogeochemical implications for forest management. For Ecol Manage. 2014;334:7484. https://doi.org/10.1016/j.foreco.2014.08.033.
109. Ågren A, Lidberg W, Ring E. Mapping temporal dynamics in a forest stream network-implications for riparian forest management. Forests. 2015;6:2982-3001. https://doi.org/10.3390/f6092 982.

110. Bartels SF, Caners RT, Ogilvie J, White B, Macdonald SE. Relating bryophyte assemblages to a remotely sensed depthto-water index in boreal forests. Front Plant Sci. 2018;9:858. https://doi.org/10.3389/fpls.2018.00858.

111. Bjelanovic I, Comeau P, White B. High resolution site index prediction in boreal forests using topographic and wet areas mapping attributes. Forests. 2018;9:113. https://doi.org/10.3390/ f9030113.

112. Oltean GS, Comeau PG, White B. Carbon isotope discrimination by Picea glauca and Populus tremuloides is related to the topographic depth to water index and rainfall. Can J For Res. 2016;46:1225-33. https://doi.org/10.1139/cjfr-2015-0491.

Publisher's Note Springer Nature remains neutral with regard to jurisdictional claims in published maps and institutional affiliations. 


\section{Authors and Affiliations}

\section{Stephan Hoffmann ${ }^{1,2}\left(\mathbb{D} \cdot\right.$ Marian Schönauer ${ }^{2}$ (D) Joachim Heppelmann ${ }^{1}$ (i) $\cdot$ Antti Asikainen ${ }^{3} \cdot$ Emmanuel Cacot $^{4}$.

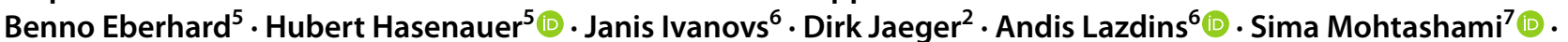

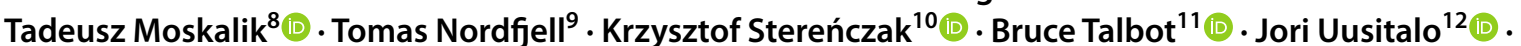 Morgan Vuillermoz ${ }^{13} \cdot$ Rasmus Astrup $^{1}$}

\author{
Marian Schönauer \\ marian.schoenauer@uni-goettingen.de \\ Joachim Heppelmann \\ joachim.heppelmann@nibio.no \\ Antti Asikainen \\ antti.asikainen@1uke.fi \\ Emmanuel Cacot \\ emmanuel.cacot@unisylva.com \\ Benno Eberhard \\ benno.eberhard@boku.ac.at \\ Hubert Hasenauer \\ hubert.hasenauer@boku.ac.at \\ Janis Ivanovs \\ janis.ivanovs@silava.lv \\ Dirk Jaeger \\ dirk.jaeger@uni-goettingen.de \\ Andis Lazdins \\ andis.lazdins@silava.lv \\ Sima Mohtashami \\ sima.mohtashami@skogforsk.se \\ Tadeusz Moskalik \\ tadeusz_moskalik@sggw.edu.pl \\ Tomas Nordfjell \\ Tomas.Nordfjell@slu.se \\ Krzysztof Stereńczak \\ K.Sterenczak@ibles.waw.pl \\ Bruce Talbot \\ bruce@sun.ac.za \\ Jori Uusitalo \\ jori.uusitalo@helsinki.fi
}

Morgan Vuillermoz

Morgan.Vuillermoz@fcba.fr

Rasmus Astrup

rasmus.astrup@nibio.no

1 Division of Forest and Forest Resources, Norwegian Institute of Bioeconomy Research (NIBIO), Ås, Norway

2 Department for Forest Work Science and Engineering, University of Göttingen, Göttingen, Germany

3 Natural Resource Institute of Finland (Luke), Joensuu, Finland

4 Forestry Cooperative UNISYLVA, Limoges, France

5 Institute of Silviculture, University of Natural Resources and Life Sciences (BOKU), Vienna, Austria

6 Latvian State Forest Research Institute (Silava), Salaspils, Latvia

7 The Forestry Research Institute of Sweden (Skogforsk), Uppsala, Sweden

8 Department of Forest Utilization, Warsaw University of Life Sciences (SGGW), Warsaw, Poland

9 Department of Forest Biomaterials and Technology, Swedish University of Agricultural Sciences (SLU), Umeå, Sweden

10 Forest Research Institute, Sękocin Stary, Poland

11 Department of Forest and Wood Science, Stellenbosch University, Stellenbosch, South Africa

12 Department of Forest Sciences, University of Helsinki, Helsinki, Finland

13 Technological Institute (FCBA), Champs-sur-Marne, France 